\title{
Shewanella vesiculosa sp. nov., a psychrotolerant bacterium isolated from an Antarctic coastal area
}

\author{
Correspondence \\ Elena Mercadé \\ mmercade@ub.edu
}

\author{
Núria Bozal, Mª Jesús Montes, David Miñana-Galbis, Angeles Manresa \\ and Elena Mercadé
}

Laboratori de Microbiologia, Facultat de Farmacia, Universitat de Barcelona, Av. Joan XXIII s/n, 08028 Barcelona, Spain

\begin{abstract}
Two strains of psychrotolerant bacteria, designated $\mathrm{M}^{\top}$ and $\mathrm{M} 5$, isolated from Antarctic coastal marine environments were studied to determine their taxonomic position. The organisms comprised Gram-negative, rod-shaped, facultatively anaerobic cells that were motile by means of single polar flagella. Neither of the bacterial isolates had a requirement for $\mathrm{Na}^{+}$. These two psychrotolerant strains grew at temperatures ranging from -4 to $30{ }^{\circ} \mathrm{C}$. Both strains were capable of producing $\mathrm{H}_{2} \mathrm{~S}$ from thiosulfate and were able to use sodium nitrate and trimethylamine $\mathrm{N}$-oxide as terminal electron acceptors during anaerobic growth. 16S rRNA gene sequence analysis placed $\mathrm{M} 7^{\top}$ and $\mathrm{M} 5$ within the genus Shewanella; the strains showed the highest similarity (99.9 and $99.2 \%$ respectively) with respect to the type strains of Shewanella livingstonensis and Shewanella frigidimarina. However the levels of gyrB sequence similarity between strain $M 7^{\top}$ and the type strains of S. livingstonensis and S. frigidimarina were 87.6 and 87.4\%, respectively. DNA-DNA hybridization experiments performed between the Antarctic isolate $M 7^{\top}$ and S. livingstonensis LMG $19866^{\top}$ and S. frigidimarina LMG $19475^{\top}$ revealed levels of relatedness of 32 and $35 \%$, respectively. Strain M5 showed $100 \%$ DNA relatedness with respect to strain $M 7^{\top}$. The DNA G $+C$ content of these bacteria was $42 \mathrm{~mol} \%$. Several phenotypic characteristics, the cellular fatty acid compositions and the quinone content of strains $\mathrm{M7}^{\top}$ and M5 served to differentiate them from related shewanellae. On the basis of the data from this polyphasic taxonomic study, $\mathrm{M}^{\top}$ and $\mathrm{M} 5$ constitute a single genospecies. They represent a novel species of the genus Shewanella, for which the name Shewanella vesiculosa sp. nov. is proposed. The type strain is $M 7^{\top}$ (=LMG $24424^{\top}=$ CECT $7339^{\top}$ ).
\end{abstract}

The genus Shewanella was first described by MacDonell \& Colwell (1985). The definition was based almost entirely on rRNA structure and included only the description 'straight or curved rods, Gram-negative, non-pigmented, motile by polar flagella, chemo-organotrophic, oxidase-positive, generally associated with aquatic or marine habitats. $\mathrm{G}+\mathrm{C}$ mol\% 44-47'. Although the taxonomy of this group has been developed in the last decade, Shewanella putrefaciens has been studied since its first description as Achromobacter putrefaciens by Derby \& Hammer (1931), because of its special importance in the areas of applied and environmental microbiology.

The GenBank/EMBL/DDBJ accession numbers for the 16S rRNA gene sequences of strains $M 7^{\top}$ and $M 5$ are $A M 980877$ and $A M 980878$, respectively, and those for the gyrB gene sequences of strains $M 7^{\top}$ and S. livingstonensis NF22 ${ }^{\top}$ are EU702750 and EU702751, respectively.

Transmission electron micrographs of ultrathin sections of cells of strain $M 7^{\top}$ and details of the cellular fatty acid compositions for strains $M 7^{\top}$ and M5 are presented as supplementary material available with the online version of this paper.
Currently, more than 40 species are assigned to the genus Shewanella on the basis of genetic and phenotypic analyses (http://www.bacterio.cict.fr/s/shewanella.html). The shewanellae constitute a diverse group of facultatively anaerobic bacteria. Their ability to utilize a variety of final electron acceptors in the absence of oxygen and their capacity to grow at low temperatures and various salt concentrations and barometric pressures allow them to survive in extreme environments, such as those of Antarctica (Bowman et al., 1997; Bozal et al., 2002). Because of their potential uses in bioremediation and energy-generating biocatalysis, shewanellae are being studied intensively, not only taxonomically, but also in terms of genomics, ecology and biotechnology (Venkateswaran et al., 1999; Hau \& Gralnick, 2007).

During the characterization of psychrotolerant organisms isolated from Antarctica, strains $M 7^{\mathrm{T}}$ and $\mathrm{M} 5$ were recovered from marine sediments collected at Deception Island (South Shetland Islands). Sample aliquots were removed with a platinum loop and were diluted in Ringer solution (Oxoid). Marine agar (Difco) and tryptic soy agar 
(TSA; Oxoid) plates were inoculated with loopfuls of several sample dilutions by using the streak-plate method to obtain isolated colonies. Plates were incubated for 7 days at $15{ }^{\circ} \mathrm{C}$. Growth was observed on both media. Isolates were maintained aerobically on TSA slopes at $4{ }^{\circ} \mathrm{C}$ and also at $-80{ }^{\circ} \mathrm{C}$ on cryo-beads (AES Laboratoire).

The morphology, size and shape of cells grown on TSA at $15{ }^{\circ} \mathrm{C}$ were determined by means of negative staining (uranyl acetate at $2 \%, \mathrm{w} / \mathrm{v}$ ) and transmission electron microscopy (JEOL 1010) of ultrathin sections after freeze fixation and freeze-substitution (Nevot et al., 2006). Motility was investigated by means of phase-contrast microscopy. Oxidase, catalase and urease activities, nitrate reduction and hydrolysis of casein, lecithin, gelatin, DNA, starch and Tween 80 were determined according to Barrow \& Feltham (1993). Utilization of carbohydrates, enzyme production and additional characteristics were determined by using API $50 \mathrm{CH}$, API ZYM and API 20NE strips (bioMérieux). $\mathrm{NaCl}$ tolerance was measured on nutrient agar (Cultimed) containing $0-10 \%(\mathrm{w} / \mathrm{v}) \mathrm{NaCl}$; plates were incubated at $15{ }^{\circ} \mathrm{C}$ for 14 days. The temperature range for growth was determined on TSA incubated for 14 days at temperatures from -4 to $37{ }^{\circ} \mathrm{C}$. The $\mathrm{pH}$ range for growth was established in tryptic soy broth (TSB; Difco) at $\mathrm{pH} 4.0-10.0$ (using increments of $0.5 \mathrm{pH}$ units) at $15{ }^{\circ} \mathrm{C}$ for 10 days. Anaerobic growth tests were performed in a modified YP liquid medium prepared according to Toffin et al. (2004). Trimethylamine $\mathrm{N}$-oxide $(10 \mathrm{mM})$ and sodium nitrate $(3 \mathrm{mM})$ were tested as electron acceptors, with $10 \mathrm{mM}$ lactate as the electron donor and carbon source. Anaerobic conditions were generated in anaerobic chambers (Oxoid) with AnaeroGen (Oxoid) and an anaerobic indicator (Oxoid) and plates were incubated at $15{ }^{\circ} \mathrm{C}$ for 10 days. Before storage at $15{ }^{\circ} \mathrm{C}$, anaerobic jars were kept overnight at $-4{ }^{\circ} \mathrm{C}$ to ensure that anoxic conditions had developed before strain growth could occur. Growth on the plates was compared with growth on control plates containing the same medium but without an organic carbon substrate.

The Antarctic bacterial isolates $\mathrm{M}^{\mathrm{T}}$ and $\mathrm{M} 5$ comprised Gram-negative, rod-shaped, non-spore-forming cells. On TSA incubated at $15{ }^{\circ} \mathrm{C}$ for 2 days, colonies were circular, smooth, convex, slightly mucous and 1-2 $\mathrm{mm}$ in diameter. After 1 week, colonies became more mucous and brownish-coloured. On marine agar, colonies were similar but orange in colour. Diffusible pigments and bioluminescence were not observed. Transmission electron microscopy of ultrathin sections of cells of strain $\mathrm{M} 7^{\mathrm{T}}$ showed that large numbers of outer-membrane vesicles were released (see Supplementary Fig. S1, available in IJSEM Online). Cells were motile by means of single polar flagella. Neither isolate required $\mathrm{Na}^{+}$for growth. The strains were chemoorganotrophic and capable of respiratory and fermentative metabolism. Both strains were positive for cytochrome oxidase and catalase. They reduced nitrate to nitrite, and nitrogen gas was not formed from nitrite. $M 7^{\mathrm{T}}$ and $\mathrm{M} 5$ were able to grow anaerobically by reducing trimethyla- mine $\mathrm{N}$-oxide or sodium nitrate while using DL-lactate as the electron donor.

The results of the morphological and phenotypic investigations are given in the species description and in Table 1. Phenotypic studies showed that the isolates displayed characteristics consistent with those for the genus Shewanella, but strain $\mathrm{M}^{\mathrm{T}}$ differed significantly from related species (Shewanella livingstonensis, S. frigidimarina, S. hafniensis, S. putrefaciens, S. gaetbuli and S. morhuae) in terms of several phenotypic properties, such us temperature requirements, $\mathrm{NaCl}$ requirements, enzyme activities and metabolism of certain sugars.

Cellular fatty acid and isoprenoid quinone compositions were determined for cell mass grown on TSB agar (30 g TSB, $15 \mathrm{~g}$ agar; Oxoid) for 4 days at $20{ }^{\circ} \mathrm{C}$, as described previously (Bozal et al., 2002). The most abundant fatty acids were summed feature $3\left(\mathrm{C}_{16: 1} \omega 7 \mathrm{c}\right.$ and/or iso- $\mathrm{C}_{15: 0} 2$ $\mathrm{OH} ; 25.41 \%$ in strain $\left.\mathrm{M}^{\mathrm{T}}\right)$, iso- $\mathrm{C}_{13: 0}(13.20 \%)$, iso- $\mathrm{C}_{15: 0}$ $(9.70 \%), \mathrm{C}_{16: 0}(9.73 \%), \mathrm{C}_{17: 1} \omega 8 c(7.84 \%)$ and $\mathrm{C}_{15: 0}$ (5.73\%) (see Supplementary Table S1). The isolates had cellular fatty acid profiles that were similar to those of phylogenetically closely related type strains of S. livingstonensis and S. frigidimarina; however, strains $M 7^{\mathrm{T}}$ and M5 had lower levels of monounsaturated fatty acids and increased levels of terminally branched saturated fatty acids and, unlike $S$. frigidimarina, strain $\mathrm{M}^{\mathrm{T}}$ did not produce eicosapentaenoic acid $\left(\mathrm{C}_{20: 5} \omega 3\right)$ (Nichols et al., 1994; Bowman et al., 1997; Venkateswaran et al., 1999; Bozal et al., 2002). Strains $M 7^{\mathrm{T}}$ and $\mathrm{M} 5$ contained ubiquinones (Q-7, Q-8) and menaquinones (MK-7 and MMK-7) that are commonly found in Shewanella species (Bozal et al., 2002; Bowman, 2005).

Total DNA for complete 16S rRNA gene sequence analysis was prepared according to the protocol of Niemann et al. (1997). A total of $1495 \mathrm{nt}$ from the 16S rRNA gene were sequenced, as described previously by Bozal et al. (2002). A phylogenetic analysis was performed using the software package BioNumerics (Applied Maths). Distance analysis and clustering was done using the neighbour-joining method (Saitou \& Nei, 1987). For strain $\mathrm{M}^{\mathrm{T}}$ and $S$. livingstonensis LMG $19866^{\mathrm{T}}$, the gyrB gene was PCRamplified with universal primer sets, as described by Yamamoto \& Harayama (1995), and subsequently sequenced. The identity of a given PCR product was verified by means of bidirectional sequencing analysis. Multiple alignment, distance matrix analysis and phylogenetic analysis of $g y r B$ sequences obtained in this study and others available in the public databases were performed using MEGA, version 4.0 (Tamura et al., 2007). A phylogenetic tree was constructed using the neighbourjoining method (with Kimura's two-parameter model and the pairwise deletion option) and its topological robustness was evaluated by means of a bootstrap analysis of 1000 replicates. For DNA-DNA hybridizations and determination of $\mathrm{G}+\mathrm{C}$ content, total DNA was prepared according to a modification of the procedure of Wilson (1987). The 
$\mathrm{G}+\mathrm{C}$ content was determined by using the HPLC technique, as described by Mesbah et al. (1989). DNADNA hybridizations were performed at $47^{\circ} \mathrm{C}$ according to a modification (Goris et al., 1998; Cleenwerck et al., 2002) of the method described by Ezaki et al. (1989).

The 16S rRNA gene phylogenetic studies confirmed that the Antarctic isolates (strains $\mathrm{M}^{\mathrm{T}}$ and M5) were members of the genus Shewanella. The highest levels of 16S rRNA gene sequence similarity were found with $S$. livingstonensis LMG $19866^{\mathrm{T}}(99.9 \%)$ and S. frigidimarina ACAM $591^{\mathrm{T}}$ $(99.2 \%)$; lower levels of similarity (97.0-97.5\%) occurred with strains of other Shewanella species with validly published names (Fig. 1). Strain M5 showed $100.0 \% 16 \mathrm{~S}$ rRNA gene sequence similarity with respect to $\mathrm{M}^{\mathrm{T}}$, indicating that these strains probably belong to the same species. On the basis of $\operatorname{gyr} B$ gene sequences, the nearest neighbours of strain $\mathrm{M}^{\mathrm{T}}$ were again the type strains of $S$. livingstonensis and S. frigidimarina (Fig. 2), but with sequence similarities of 87.6 and $87.4 \%$, respectively. These similarity values are lower than the $90 \%$ species cut-off value proposed for Shewanella by Venkateswaran et al. (1999), and the gyrB sequence of strain $M 7^{\mathrm{T}}$ formed a monophyletic branch in the tree shown in Fig. 2, suggesting that this strain represents a novel Shewanella species. To verify the taxonomic position of strain $M 7^{\mathrm{T}}$, DNA-DNA hybridizations were performed with $S$. livingstonensis LMG $19866^{\mathrm{T}}$ and S. frigidimarina LMG $19475^{\mathrm{T}}$. The low DNA-DNA reassociation values (32 and 35\% with respect to $S$. livingstonensis LMG $19866^{\mathrm{T}}$ and $S$. frigidimarina LMG $19475^{\mathrm{T}}$, respectively) and the results of the 16S rRNA and gyrB gene sequence analyses indeed demonstrated the distinct position of strain $\mathrm{M}^{\mathrm{T}}$ within the genus Shewanella (Wayne et al., 1987). Strain M5 showed $100 \%$ DNA relatedness with respect to $\mathrm{M}^{\mathrm{T}}$ and it can be concluded that $\mathrm{M} 5$ and $\mathrm{M}^{\mathrm{T}}$ belong to the same genospecies. Their DNA G+C content (42 mol\%) lies

Table 1. Differential characteristics for strains $M 7^{\top}$ and $M 5$ and their closest phylogenetic neighbours

Strains/species: $1, \mathrm{M}^{\mathrm{T}}$ (strain M5 showed identical results with the exception that it did not grow with $7 \% \mathrm{NaCl}$ ); 2, S. livingstonensis (data from Bozal et al., 2002); 3, S. frigidimarina (Bowman et al., 1997); 4, S. hafniensis (Satomi et al., 2006); 5, S. putrefaciens (Venkateswaran et al., 1999); 6, S. gaetbuli (Yoon et al., 2004); 7, S. morhuae (Satomi et al., 2006). All species are Gram-negative rods that are motile by means of single polar flagella and all are positive for growth at $4{ }^{\circ} \mathrm{C}$ at $3 \% \mathrm{NaCl}$ and for catalase and oxidase activities. +, Positive; -, negative; ND, no data available; $\mathrm{v}-$, $11-$ $89 \%$ of strains negative, type strain negative.

\begin{tabular}{|c|c|c|c|c|c|c|c|}
\hline Characteristic & 1 & 2 & 3 & 4 & 5 & 6 & 7 \\
\hline Cell length $(\mu \mathrm{m})$ & $1.5-3$ & $1-3$ & $1.0-2.5$ & $1.0-1.2$ & ND & $1.5-3.0$ & $1.0-1.2$ \\
\hline Cell diameter $(\mu \mathrm{m})$ & 0.5 & 0.4 & $0.5-0.8$ & $0.5-0.7$ & ND & $0.5-0.7$ & $0.5-0.7$ \\
\hline \multicolumn{8}{|l|}{ Growth at/with: } \\
\hline $30{ }^{\circ} \mathrm{C}$ & + & - & - & + & + & + & + \\
\hline $37^{\circ} \mathrm{C}$ & - & - & - & - & + & + & - \\
\hline $0 \% \mathrm{NaCl}$ & + & + & + & + & + & - & ND \\
\hline $7 \% \mathrm{NaCl}$ & + & - & + & - & - & + & - \\
\hline Reduction of nitrate to nitrite & + & + & + & + & + & - & + \\
\hline Production of $\mathrm{H}_{2} \mathrm{~S}$ & + & + & + & + & + & - & + \\
\hline \multicolumn{8}{|l|}{ Enzyme activities } \\
\hline Lipase (C14) & + & - & ND & ND & ND & - & ND \\
\hline$\alpha$-Chymotrypsin & + & - & ND & ND & + & + & ND \\
\hline$\beta$-Galactosidase (ONPG) & + & + & $\mathrm{v}-$ & $\mathrm{ND}$ & ND & - & $\mathrm{ND}$ \\
\hline$N$-Acetyl- $\beta$-glucosaminidase & + & - & $\mathrm{ND}$ & $\mathrm{ND}$ & - & + & $\mathrm{ND}$ \\
\hline Cystine arylamidase & - & + & ND & ND & ND & - & ND \\
\hline DNase & + & - & + & + & + & ND & + \\
\hline Lecithinase & + & - & + & ND & ND & ND & ND \\
\hline Gelatinase & + & + & + & + & - & + & + \\
\hline \multicolumn{8}{|l|}{ Utilization of: } \\
\hline D-Galactose & + & + & $\mathrm{v}-$ & ND & + & - & ND \\
\hline Glucose & + & + & + & + & - & ND & - \\
\hline Sucrose & + & + & + & - & - & - & - \\
\hline D-Xylose & - & + & $\mathrm{v}-$ & $\mathrm{ND}$ & $\mathrm{ND}$ & $\mathrm{ND}$ & $\mathrm{ND}$ \\
\hline $\mathrm{N}$-Acetylglucosamine & + & + & - & + & + & $\mathrm{ND}$ & + \\
\hline Trehalose & - & + & + & $\mathrm{ND}$ & ND & ND & ND \\
\hline Malate & + & - & + & + & + & - & + \\
\hline D-Ribose & - & + & ND & ND & ND & ND & ND \\
\hline DNA G $+C$ content $(\mathrm{mol} \%)$ & 42 & 41 & $40-43$ & 47 & $43-47$ & 42 & 44 \\
\hline
\end{tabular}




\begin{tabular}{|c|c|c|c|c|}
\hline & Similarity (\%) & \multirow[b]{2}{*}{$\stackrel{8}{\circ}$} & & \\
\hline 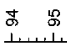 & \& & & & \\
\hline & $\sqrt{100}$ & $\mathrm{HJ} 039^{\mathrm{T}}$ & S. spongiae & DQ167234 \\
\hline & & UST040317-058 & S. irciniae & DQ180743 \\
\hline & $\sqrt{52}$ & OS $217^{\top}$ & S. denitrificans & AJ311964 \\
\hline & 52 & $\mathrm{TF}-27^{\mathrm{T}}$ & S. gaetbuli & AY190533 \\
\hline & 63 & $\mathrm{LT}_{1} 7^{\mathrm{T}}$ & S. donghaensis & AY326275 \\
\hline & 100 & ACEM $9^{\top}$ & S. olleyana & AF295592 \\
\hline & & KMM $3597^{\top}$ & S. pacifica & AF500075 \\
\hline & ப58 & KMM 3299' & S. japonica & AF145921 \\
\hline & & ACAM $591^{\top}$ & S. frigidimarina & U85903 \\
\hline & 100 & $M 7^{T}$ & & AM980877 \\
\hline & 4100 & LMG $19866^{\top}$ & S. livingstonensis & AJ300834 \\
\hline & $\left.100 \quad\right|^{100}$ & M5 & & AM980878 \\
\hline & $\Gamma$ & $\mathrm{P} 010^{\top}$ & S. hafniensis & AB205566 \\
\hline & $\sqrt{67}$ & $\mathrm{LT} 13 \mathrm{a}^{\top}$ & S. profunda & AY445591 \\
\hline & $b^{3}$ & ATCC $8071^{\top}$ & S. putrefaciens & X82133 \\
\hline & & 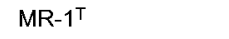 & S. oneidensis & AF005251 \\
\hline & 14 & NCTC $10735^{\top}$ & S. baltica & AJ000214 \\
\hline & 90464 & $\mathrm{~T} 147^{\top}$ & S. glacialipiscicola & AB205571 \\
\hline & & $\mathrm{U} 1417^{\top}$ & S. morhuae & AB205576 \\
\hline & 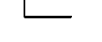 & ССТСС M 203093' & S. decolorationis & AJ609571 \\
\hline & & ATCC $51192^{\top}$ & S. algae & AF005249 \\
\hline
\end{tabular}

Fig. 1. Neighbour-joining phylogenetic tree, based on $16 \mathrm{~S}$ rRNA gene sequences, showing the position of Antarctic isolates $M 7^{\top}$ and M5 among neighbouring species of the genus Shewanella. Bootstrap percentages $>50 \%$ (based on 1000 replications) are shown at branch points.

within the range described for members of the genus Shewanella.

\section{Description of Shewanella vesiculosa sp. nov.}

Shewanella vesiculosa (ve.si.cu.lo'sa. L. fem. adj. vesiculosa full of blisters, vesiculous).

Cells are rod-shaped $(0.5 \mu \mathrm{m}$ wide and $1.5-3 \mu \mathrm{m}$ long $)$, Gram-negative, facultatively anaerobic and non-sporeforming. Cells are motile by means of single polar flagella. After $48 \mathrm{~h}$ incubation at $15{ }^{\circ} \mathrm{C}$ on TSA, colonies are 1$2 \mathrm{~mm}$ in diameter, smooth, round with regular edges, slightly mucous and slightly brownish. The growth temperature ranges from -4 to $30{ }^{\circ} \mathrm{C}$ (optimum 15$20{ }^{\circ} \mathrm{C}$ ), the $\mathrm{pH}$ range for growth is $6.0-8.5$ (optimum approx. $\mathrm{pH}$ 7.5) and sodium ions are not required for growth. Optimal growth occurs in the presence of $2 \%$ $\mathrm{NaCl}(\mathrm{w} / \mathrm{v})$; no growth in the presence of $>7 \% \mathrm{NaCl}$. Positive for oxidase, catalase, alkaline phosphatase, acid phosphatase, esterase (C4), esterase lipase (C8), lipase (C14), leucine arylamidase, valine arylamidase, $\alpha$-chymotrypsin, naphthol-AS-BI-phosphohydrolase, $\alpha$-glucosidase, $\beta$-glucosidase, $\beta$-galactosidase and $N$-acetyl- $\beta$-glucosaminidase, but negative for cystine arylamidase, trypsin, $\alpha$ galactosidase, $\beta$-glucuronidase, $\alpha$-mannosidase and $\alpha$ fucosidase. Positive for hydrolysis of aesculin, Tween 80 , gelatin, casein and lecithin, but negative for hydrolysis of urea and starch. Hydrogen sulfide is produced from thiosulfate. Cells are able to grow anaerobically by reducing trimethylamine $\mathrm{N}$-oxide and sodium nitrate with lactate as the electron donor. With the API $50 \mathrm{CH}$ test, growth is positive for D-glucose, D-galactose, D-mannitol, $\mathrm{N}$-acetylglucosamine, cellobiose, maltose, melibiose, malate and sucrose. The most abundant fatty acids are summed feature

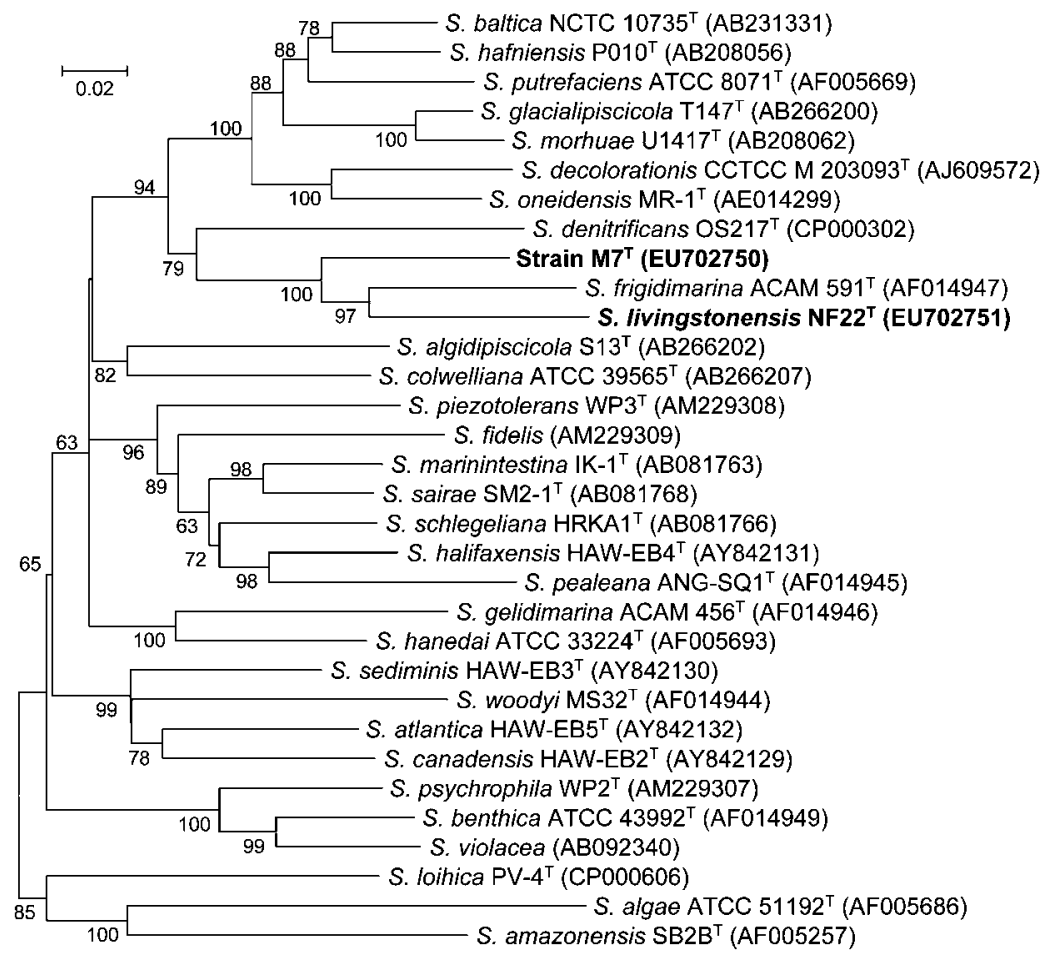

Fig. 2. Neighbour-joining phylogenetic tree based on gyrB sequences of strains $\mathrm{M}^{\top}$ and S. livingstonensis $\mathrm{NF}^{2} 2^{\top}$ (determined in this study) and strains of the genus Shewanella. Bootstrap percentages $>50 \%$ (based on 1000 replicates) are shown. Bar, 2\% sequence divergence. 
$3\left(\mathrm{C}_{16: 1} \omega 7 c\right.$ and/or iso- $\left.\mathrm{C}_{15: 0} 2-\mathrm{OH}\right)$, iso- $\mathrm{C}_{13: 0}$, iso- $\mathrm{C}_{15: 0}$, $\mathrm{C}_{16: 0}, \mathrm{C}_{17: 1} \omega 8 c$ and $\mathrm{C}_{15: 0}$. The quinone composition of the type strain is Q-7 (50.5\%), Q-8 (25.3\%), MK-7 $(14.4 \%)$ and MMK-7 (9.8\%). The DNA G + C content of the type strain is $42 \mathrm{~mol} \%$.

The type strain, $\mathrm{M} 7^{\mathrm{T}}$ (=LMG $24424^{\mathrm{T}}=\mathrm{CECT} 7339^{\mathrm{T}}$ ), was isolated from marine sediments collected from Deception Island (South Shetland Islands, Antarctica).

\section{Acknowledgements}

This paper is dedicated to the memory of Jesús Guinea Sánchez, who isolated these Antarctic strains. We would like to thank Josefina Castellví for providing Antarctic samples. We gratefully acknowledge the assistance of F. García (Departament d'Agricultura, Ramaderia i Pesca, Generalitat de Catalunya, Spain) with the fatty acid analysis. We are grateful to I. Casals for help with quinone identification and to C. López-Iglesias for transmission electron microscopy support (Serveis Científico Tècnics de la Universitat de Barcelona). We acknowledge the BCCM/LMG Identification Service (Universiteit Gent, Ghent, Belgium) for performing hybridization analyses and $16 \mathrm{~S}$ rRNA gene sequence analysis. This research was supported by the Government of Spain (CICYT project CTQ 2007-60749/PPQ) and by the Autonomous Government of Catalonia (grant 2005SGR00066).

\section{References}

Barrow, G. I. \& Feltham, R. K. A. (1993). Cowan and Steel's Manual for the Identification of Medical Bacteria, 3rd edn. Cambridge: Cambridge University Press.

Bowman, J. P. (2005). Genus XIII. Shewanella MacDonell and Colwell $1986,355^{\mathrm{VP}}$. In Bergey's Manual of Systematic Bacteriology, 2nd edn, vol. 2, part B, pp. 480-491. Edited by D. J. Brenner, N. R. Krieg, J. T. Staley \& G. M. Garrity. New York: Springer.

Bowman, J. P., McCammon, S. A., Nichols, D. S., Skerratt, J. H., Rea, S. M., Nichols, P. D. \& McMeekin, T. A. (1997). Shewanella gelidimarina sp. nov. and Shewanella frigidimarina sp. nov., novel Antarctic species with the ability to produce eicosapentaenoic acid $(20: 5 \omega 3)$ and grow anaerobically by dissimilatory $\mathrm{Fe}(\mathrm{III})$ reduction. Int J Syst Bacteriol 47, 1040-1047.

Bozal, N., Montes, M. J., Tudela, E., Jiménez, F. \& Guinea, J. (2002). Shewanella frigidimarina and Shewanella livingstonensis sp. nov. isolated from Antarctic coastal areas. Int J Syst Evol Microbiol 52, 195-205.

Cleenwerck, I., Vandemeulebroecke, K., Janssens, D. \& Swings, J. (2002). Re-examination of the genus Acetobacter, with descriptions of Acetobacter cerevisiae sp. nov. and Acetobacter malorum sp. nov. Int J Syst Evol Microbiol 52, 1551-1588.

Derby, H. A. \& Hammer, B. W. (1931). Bacteriology of butter. IV. Bacteriological studies on surface taint butter. Iowa Agric Exp Stn Res Bull 145, 389-416.

Ezaki, T., Hashimoto, Y. \& Yabuuchi, E. (1989). Fluorometric deoxyribonucleic acid-deoxyribonucleic acid hybridization in microdilution wells as an alternative to membrane filter hybridization in which radioisotopes are used to determine genetic relatedness among bacterial strains. Int J Syst Bacteriol 39, 224-229.

Goris, J., Suzuki, K., De Vos, P., Nakase, T. \& Kersters, K. (1998). Evaluation of a microplate DNA-DNA hybridization method compared with the initial renaturation method. Can J Microbiol 44, $1148-1153$.

Hau, H. H. \& Gralnick, A. (2007). Ecology and biotechnology of the genus Shewanella. Annu Rev Microbiol 61, 237-258.

MacDonell, M. T. \& Colwell, R. R. (1985). Phylogeny of the Vibrionaceae, and recommendation for two new genera, Listonella and Shewanella. Syst Appl Microbiol 6, 171-182.

Mesbah, M., Premachandran, U. \& Whitman, W. B. (1989). Precise measurement of the $\mathrm{G}+\mathrm{C}$ content of deoxyribonucleic acid by highperformance liquid chromatography. Int J Syst Bacteriol 39, 159-167.

Nevot, M., Deroncele, V., López-Iglesias, C., Bozal, N., Guinea, J. \& Mercade, E. (2006). Ultrastructural analysis of the extracellular matter secreted from the psychrotolerant bacterium Pseudoalteromonas antarctica $\mathrm{NF}_{3}$. Microb Ecol 51, 501-507.

Nichols, D. S., McMeekin, T. A. \& Nichols, P. D. (1994). Manipulation of polyunsaturated, branched-chain and trans-fatty acid production in Shewanella putrefaciens strain ACAM 342. Microbiology 140, 577584.

Niemann, S., Puehler, A., Tichi, H. V., Simon, R. \& Selbitschka, W. (1997). Evaluation of the resolving power of the three different fingerprinting methods to discriminate among isolates of a natural Rhizobium meliloti population. J Appl Microbiol 82, 477-484.

Saitou, N. \& Nei, M. (1987). The neighbor-joining method: a new method for reconstructing phylogenetic trees. Mol Biol Evol 4, 406425.

Satomi, M., Fonnesbech Vogel, B., Gram, L. \& Venkateswaran, K. (2006). Shewanella hafniensis sp. nov. and Shewanella morhuae sp. nov., isolated from marine fish of the Baltic Sea. Int J Syst Evol Microbiol 56, 243-249.

Tamura, K., Dudley, J., Nei, M. \& Kumar, S. (2007). MEGA4: molecular evolutionary genetics analysis (MEGA) software version 4.0. Mol Biol Evol 24, 1596-1599.

Toffin, L., Bidault, A., Pignet, P., Tindall, B. J., Slobodkin, A., Kato, C. \& Prieur, D. (2004). Shewanella profunda sp. nov., isolated from deep marine sediment of the Nankai Trough. Int J Syst Evol Microbiol 54, 1943-1949.

Venkateswaran, K., Moser, D. P., Dollhopf, M. E., Lies, D. P., Saffarini, D. A., MacGregor, B. J., Ringelberg, D. B., White, D. C., Nishijima, M. \& other authors (1999). Polyphasic taxonomy of the genus Shewanella and description of Shewanella oneidensis sp. nov. Int J Syst Bacteriol 49, 705-724.

Wayne, L. G., Brenner, D. J., Colwell, R. R., Grimont, P. A. D., Kandler, O., Krichevsky, M. I., Moore, L. H., Moore, W. E. C., Murray, R. G. E. \& other authors (1987). International Committee on Systematic Bacteriology. Report of the ad hoc committee on reconciliation of approaches to bacterial systematics. Int J Syst Bacteriol 37, 463-464.

Wilson, K. (1987). Preparation of genomic DNA from bacteria. In Current Protocols in Molecular Biology, pp. 2.4.1-2.4.5. Edited by F. M. Ausubel, R. Brent, R. E. Kingston, D. D. Moore, J. G. Seidman, J. A. Smith \& K. Struhl. New York: Green Publishing \& Wiley-Interscience.

Yamamoto, S. \& Harayama, S. (1995). PCR amplification and direct sequencing of $g y r B$ genes with universal primers and their application to the detection and taxonomic analysis of Pseudomonas putida strains. Appl Environ Microbiol 61, 1104-1109.

Yoon, J. H., Kang, K. H., Oh, T. K. \& Park, Y. H. (2004). Shewanella gaetbuli sp. nov., a slight halophile isolated from a tidal flat in Korea. Int J Syst Evol Microbiol 54, 487-491. 